\title{
An analysis on energy efficiency initiatives in the building stock of Liege, Belgium
}

\author{
Manoj Kumar Singh ${ }^{\text {a,* }}$, Sadhan Mahapatra ${ }^{\mathrm{b}}$, Jacques Teller ${ }^{\mathrm{a}}$ \\ a Faculté des Sciences Appliquées, Department ArGEnCo, Local Environment Management and Analysis (LEMA), Université de Liège, Chemin des Chevreuils, \\ 1-4000 Liège, Belgium \\ ${ }^{\mathrm{b}}$ Department of Energy, Tezpur University, Tezpur 784028, Assam, India
}

\section{H I G H L I G H T S}

- Energy efficiency studies of building stock of Liege, Belgium.

- Energy Performance Building Directive is used as reference for analysis.

- Buildings age, built-up area and energy consumption data are used for analysis.

- Identifies the areas to improve energy efficiency of building stock.

\section{A R T I C L E I N F O}

\section{Article history:}

Received 6 March 2013

Accepted 27 July 2013

\section{Keywords:}

Building stock

Energy Performance Building Directive

Energy efficiency

\begin{abstract}
A B S T R A C T
Built environment is responsible for 60\% of total energy consumption in European countries and 128 million BOE of primary energy in Belgium. The average energy consumption in the residential buildings of Belgium is 70\% higher than the EU average and stands at $348 \mathrm{~kW} \mathrm{~h} / \mathrm{m}^{2} /$ year. Energy Performance Building Directive (EPBD) provides guidelines for energy performance analysis of buildings in Belgium. In this study, a holistic approach has been adopted to analyse the building stock of Liege, Belgium. This analysis is based on 'General Socio-economic survey 2001' and 'Housing quality survey 2006 in Walloon region' databases. It considers parameters such as buildings age, built-up area, type of heating system, type of fuel used, adjacency, insulation of roofs and walls and energy consumption etc. for an in depth analysis. This study concludes that about $69 \%$ of buildings which are constructed before 1945 needs serious renovation towards the improvement of roof and external wall insulation level. It then successfully identifies specific areas which need detailed study to evaluate the comfort status in the existing building stock, improvement of insulation level and its effect on heating energy consumption as well as the economic analysis on energy efficiency measurements.
\end{abstract}

(c) 2013 Elsevier Ltd. All rights reserved.

\section{Introduction}

Energy consumption has significant social, economical and environmental consequences (Georgiadu et al., 2012). The availability and accessibility to energy is directly linked to indoor thermal comfort and increases in productivity (Salat, 2009; Verhoeven, 2009). According to Stern review on economics and climate change, built environment is responsible for 60\% of energy consumption in European countries (Annunziata et al., 2013;IEA, 2007; Fracastoro and Serraino, 2011; Stern, 2007). Primary energy consumption in Belgium was 36,936 toe ${ }^{1}$ in 2008 (EAS (Energy Annual Statistics), 2011; EIA, 2010; Eurostat, 2011). Fig. 1 presents

\footnotetext{
* Corresponding author. Tel.: + 32 43669644; fax: + 3243662909.

E-mail address: mksinghtu@gmail.com (M.K. Singh).

${ }^{1}$ toe: Tones of oil equivalent.
}

the percentage of total primary energy consumption in various sectors in EU-27(European Union of 27 countries) and Belgium in 2008. It is found from Fig. 1 that the trend of energy consumption across different sectors in Belgium is different than that of EU-27. In Belgium, industry sector consumed most of the primary energy whereas in EU-27 transport sector was the highest consumer of primary energy in 2008 (EIA, 2010; IEA Annex 53, 2009;IEA, 2010; Stern, 2007). The residential buildings accounts for $73 \%$ and tertiary buildings account for $27 \%$ of primary energy consumption in the building sector of Belgium (EAS (Energy Annual Statistics), 2011). Energy consumption in the residential buildings of Belgium is $70 \%$ higher than the EU average and appears that the sector is less energy efficient than its counterparts in other EU countries (Bartiaux et al., 2006; Mlecnic et al., 2010; Panayiotou et al., 2010; Theodoridou et al., 2011a,b; Attia, 2011; Cyx et al., 2011; D'haeseleer et al., 2009; De Herde et al., 2009). Fig. 2 represents green house gases emission of different sectors of Belgium and EU-27 in 2008. It can be observed form Fig. 2 that in Belgium GHG emission due to 


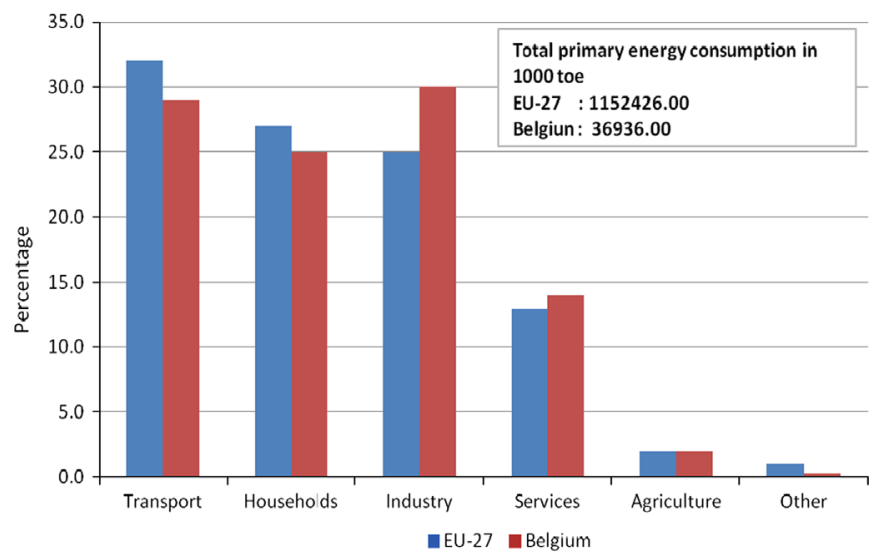

Fig. 1. Primary energy consumption in various sectors of EU-27 and Belgium in 2008 (EAS, 2011; EIA, 2010; EIA, 2013; Eurostat, 2011).

heating of buildings is the second largest contributor after manufacturing and construction sector in 2008 (EIA, 2010; EIA, 2013; Eurostat, 2011). By contrast for EU-27, transport sector was the highest contributor towards GHG emission in 2008. Fig. 3 represents the share of various primary energy consumptions in households for the year 1999 and 2009. It can be observed from Fig. 3 that the dependency on oil products has been reduced in 2009 and there is a gradual shift towards cleaner primary energy sources like natural gas and renewable energy (D'haeseleer et al., 2009; ECONOTEC, 2007; EAS (Energy Annual Statistics), 2011). The primary energy consumption is expected to reach 390 million $\mathrm{BOE}^{2}$ in 2020 and will stabilize around 366 million BOE in 2030 when business as usual (BAU) scenario is considered ( $\mathrm{D}^{\prime}$ haeseleer et al., 2009; Broin et al., 2013; Verhoeven, 2009). The estimation also predicts that the energy saving potential in buildings would be in the order of 61 million BOE (48\% of 2030 primary energy consumption in BAU scenario) (D'haeseleer et al., 2009; Broin et al., 2013; Verhoeven, 2009; EIA, 2010; EIA, 2013).

Belgium is divided into three regions namely Flemish region, Brussels capital region and Walloon region. Residential building stock in these three regions of Belgium is very different from each other (Renard et al., 2008; Trachte, De Herde, 2010). Table 1 shows the different characteristics of the residential building stock regarding type, ownership, built-up area, year of construction, fuel used in heating system, type of heating system and glazing system. Table 1 is based on the dataset of SEREC survey-2004 (Bartiaux et al., 2006). Table 1 presents a broad scenario at regional level but this may be quite different at local level (De Herde et al., 2009; De Meester, 2010; de Meester et al., 2013; Evrard et al., 2011; Massart and De Herde, 2010; Georges et al., 2012). So it demands that available data must be analysed at micro (local) level to generate discrete and specific information about the characteristics of building stock. In this study, by analysing the building stock data of Liege city, we found some interesting information which presents a quite different picture compared to overall trend of Walloon region. Probable factors that might contribute to a distinct behaviour of the residential building stock of Liege are discussed in detail in later sections of the article. The information generated in this study also present a clear picture of building sector in contrast to socio-economic factors of Liege city and will contribute towards effective local policy making and urban energy planning.

\subsection{European Union Energy Performance Buildings Directive (EPBD)}

Building sector refers to both residential and tertiary buildings. Building sector accounts for $40 \%$ of total energy consumption and $36 \%$ of European $\mathrm{CO}_{2}$ emissions (European Parliament and Council, 2003, 2010a, 2010b). The energy consumption and subsequent $\mathrm{CO}_{2}$ emission have increased substantially with the growth of this sector. The industrialized countries listed in Annex I of Kyoto Protocol committed to reduce the emission by $5.2 \%$ on an average over a period of 2008-2012 relative to their annual emissions level in 1990 (base year) (European Parliament and Council, 2003, 2010a, 2010b; Roberts, 2008;). The share of building energy consumption in EU States reflects that the building sector is one of the major sources of greenhouse gas emissions, thus representing a huge potential towards improving energy efficiency and reduction in GHG emissions (European Parliament and Council, 2003, 2010a, 2010b, 2010; Anisimova, 2011). A number of studies carried out across the EU member countries on the analysis of existing building stock. Significant percentage of buildings in the existing building stock are relatively old and thus have a huge potential in energy saving and GHG emission reduction. However, these studies emphasises the importance to address the local/ regional energy driven issues and policy requirements to improve the energy efficiency (Kohler and Hassler, 2002; Balaras et al., 2007; Bradley and Kohler, 2007; Carvalho, 2012; Ekins and Lees, 2008; Meinel et al., 2009; Dascalaki et al., 2010; Tambach et al., 2010; Anisimova, 2011; Dascalaki et al., 2011; Lechtenbohmer and Schuring, 2011; Theodoridou et al., 2011a,b; Dall'O' et al., 2012). Keeping this in view, European Commission (EC) formulated a policy guidelines related to building regulations with an objective towards harmonization of rules and regulations in all the member countries. This draft has been accepted by European Parliament as 'Directive 2002/91/EC on Energy Performance of Buildings'. This directive has been revised over the period of time and the revision has been accepted by European Parliament on 19th May 2010 as 'Directive 2010/31/EU' (European Parliament and Council, 2003, 2010a, 2010b; Carvalho, 2012; Ekins and Lees, 2008). This Directive targets a reduction of GHG emissions by at least $20 \%$ by 2020 by (a) improving energy efficiency (b) reducing the consumption of fossil fuel based energy sources and (c) increasing the penetration of renewable energy (European Parliament and Council, 2003, 2010a, 2010b; Bradley and Kohler, 2007; Lechtenbohmer and Schuring, 2011). It is assumed that the directive will also play an important role in promoting energy efficiency, technological development and employment generation opportunities along with regional development (European Parliament and Council, 2010a, 2010b). It therefore adopts a holistic approach in overall performance assessment of both new and old buildings. This directive on energy performance of buildings is the main legislative instrument at EU level to achieve energy performance in buildings (Dall'O' et al., 2012). Under this directive, the member state has to enforce minimum requirements regarding the energy performance of new and existing buildings (European Parliament and Council, 2003, 2010a, 2010b).

\subsection{EPBD programme in Belgium}

Once EPBD was adopted by European Parliament and Council major issue was to implement EPBD throughout the Member States and achieve the targets set by the directive. There was hence a need of a roadmap that will lead to the successful implementation of EPBD across Member States. This thought got a major boost on 17th November 2009 when European Parliament and Council adopted a recast proposal on effective implementation of EPBD (European Parliament and Council, 2010a, 2010b; EIA, 2010). This recast laid down a roadmap to achieve the

\footnotetext{
${ }^{2}$ BOE: Barrel of oil equivalent.
} 


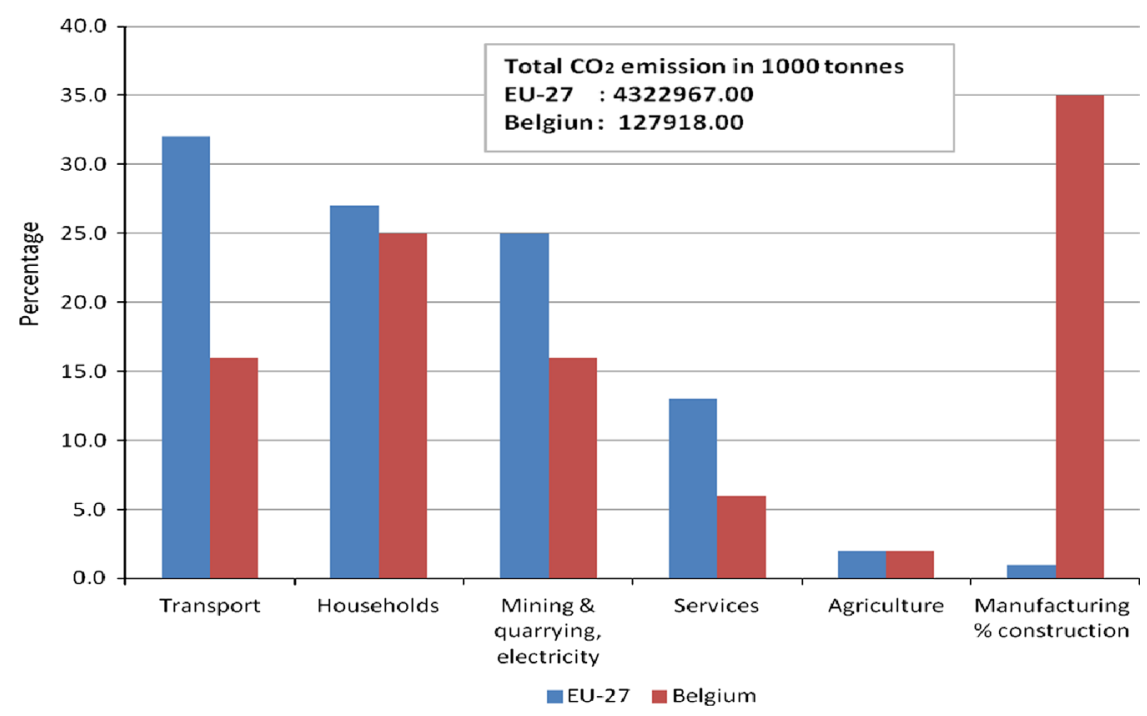

Fig. 2. $\mathrm{CO}_{2}$ emission from various sectors of EU-27 and Belgium in 2008 (EAS, 2011; EIA, 2010; EIA, 2013; Eurostat, 2011).

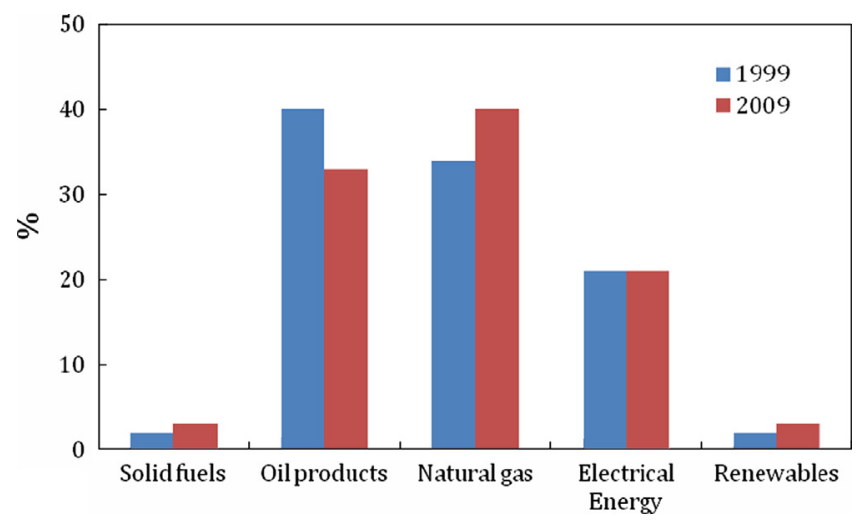

Fig. 3. Share of various energy sources in household sector (Stern, 2007).

ambitious target 2020 set by Commission such as (a) $20 \%$ reduction in energy consumption, (b) $20 \%$ reduction in $\mathrm{CO}_{2}$ emissions and (c) 20\% increase in renewable energy in energy mix (European Parliament and Council, 2010a, 2010b). It also established a long term commitment of Commission to support to trap the cost effective energy savings potential in buildings by ensuring penetration of energy efficiency measures and renewable energy in building sector (European Parliament and Council, 2010a, 2010b; EIA, 2010; Eurostat, 2011). If this is realized, it would translate to savings of $11 \%$ of final energy consumption in buildings by 2020 in EU (European Parliament and Council, 2010a, 2010b; EIA, 2013; Eurostat, 2011). Following are some highlights of recast at EU level:

- "Low energy building" definition was set to "nearly zero" energy building which means that building should be "passive solar" and use renewable energy to a large extent. Promoting decentralised energy production on site or nearby by renewable energy action plan.

- By 2020 all new buildings of EU will be "nearly zero" energy. But public buildings should be nearly zero by 2018 by promoting use of more clean energy in energy mix.

- Building sector energy requirement will be met through renewable energy.

- Large proportion of EU existing building stock is relatively old and present a huge potential for energy saving. However, no specific targets for the renovation of these building are being set. Considering the complexity of existing building, it is emphasized that member states should stimulate the transformation of existing building stock to very low energy buildings. Public sector buildings should set example for new and refurbished buildings by 2014.

- Threshold area for major renovation should be gradually reduced to cover large number of buildings (January 2013 threshold area falls to $500 \mathrm{~m}^{2}$ from $1000 \mathrm{~m}^{2}$, in July 2015 threshold area will fall to $250 \mathrm{~m}^{2}$ ).

- Harmonised calculation across member states for minimum energy requirement.

- More detailed and rigorous procedures of issuing energy performance certificates.

- Introduction of effective, proportionate and dissuasive penalties for non compliance to EPBD and effective implementation in Member States.

Considering these factors, Belgium government through its three regional governments adopted a number of measures related to

- Regulatory requirements to prescribe efficiency standards for buildings.

- Better information, training and education for professionals and support for home owners.

- Informing homeowners to help and decide on energy efficiency measures.

- Making accessible the subsidies and other financial support measures.

In Flemish region, regional legislation aiming at higher energy efficiency is the 'EnergiePrestaties en Binnenklimaat' (Energy performance and interior climate) (EPB) legislation. The Flemish region of Belgium offers (Flemish government order on 2 March 2007, amended on 23 October 2009 and 26 October 2012) a subsidy for building renovation and energy efficiency improvements related to insulating glass, high-efficiency boilers and solar heaters but wall, floor and roof insulation improvement and heat pumps are not eligible (EIA, 2013; EPBD (Implementing the Energy Performance Building Directive), 2010). The subsidy is accessible to owners-occupants with income below a certain limit. In Flemish region final low-energy level is measured by the E-standard, which is calculated by the architect. The lower the E-standard, 
Table 1

Characteristics of residential building stock in the three regions of Belgium (Flanders, Walloon and Brussels capital region) (Bartiaux et al., 2006).

\begin{tabular}{|c|c|c|c|c|}
\hline Indicator & Parameter & Flanders (\%) & Walloon (\%) & Brussels (\%) \\
\hline \multirow[t]{4}{*}{ Type of dwelling } & Apartment & 17.9 & 16.1 & 71.8 \\
\hline & Semi-detached house (2 facades) & 23.0 & 25.7 & 22.3 \\
\hline & Semi-detached house ( 3 facades) & 21.5 & 22.8 & 4.9 \\
\hline & Detached house (4 facades) & 37 & 34.7 & 1.0 \\
\hline \multirow[t]{2}{*}{ Ownership of dwelling } & Owned & 83.5 & 80 & 59.2 \\
\hline & Rent & 16.5 & 20 & 40.8 \\
\hline \multirow[t]{6}{*}{ Floor area } & $<50 \mathrm{~m}^{2}$ & 1.1 & 1.0 & 5.8 \\
\hline & $50-99 \mathrm{~m}^{2}$ & 17.7 & 13.2 & 34 \\
\hline & $100-149 \mathrm{~m}^{2}$ & 18.1 & 22.8 & 28.2 \\
\hline & $150-199 \mathrm{~m}^{2}$ & 16.6 & 14.1 & 9.7 \\
\hline & $200-249 \mathrm{~m}^{2}$ & 15.1 & 11.9 & 3.9 \\
\hline & $>250 \mathrm{~m}^{2}$ & 11.3 & 11.9 & 3.9 \\
\hline \multirow[t]{6}{*}{ Year of construction } & Before 1919 & 7.3 & 20.3 & 9.7 \\
\hline & 1919-1945 & 12.2 & 13.5 & 14.6 \\
\hline & 1946-1960 & 11.2 & 10 & 20.4 \\
\hline & 1961-1975 & 17.0 & 14.2 & 22.3 \\
\hline & $1976-1990$ & 20.3 & 19 & 11.7 \\
\hline & 1991 and later & 22.7 & 12.3 & 7.8 \\
\hline \multirow[t]{3}{*}{ Type of fuel in heating system } & Gas & 53.9 & 35.9 & 70.6 \\
\hline & Oil & 34.8 & 52.4 & 22.5 \\
\hline & Electricity & 9.1 & 6.8 & 3.9 \\
\hline \multirow[t]{2}{*}{ Type of central heating system } & Individual heating system & 93.7 & 89.4 & 53.7 \\
\hline & Other kind of heating system & 6.3 & 10.6 & 46.3 \\
\hline \multirow[t]{3}{*}{ Glazing system in houses } & Have double glazing & 67.5 & 71.9 & 54.4 \\
\hline & Mixed (single + double) glazing & 18.2 & 15.2 & 24.3 \\
\hline & No double glazing & 14.2 & 12.9 & 21.4 \\
\hline
\end{tabular}

the more the housing is low-energy. In Flanders a maximum E-standard of 100 was adopted in 2006. Through Flemish Decree of 23 May 2009 and Amendment of 19 October 2012 stipulates that new residential buildings with an E-level of E60 and new commercial buildings with an E-level of E70 shall receive a $20 \%$ property tax reduction for a period of 10 years (EIA, 2013; EPBD (Implementing the Energy Performance Building Directive), 2010). New residential buildings with an E-level of E40 shall receive a $40 \%$ property tax reduction. The regulation becomes stricter for residential buildings from 1 January 2013. In case of an E-level of E50 (E40 in 2014) a reduction of 50\% is given for a period of 5 years and a 100\% reduction for 5 years in the case of an E30 building. The aim of Flemish government is to have almost energy neutral buildings, which entails an E-standard of about E10-E30 by 2021 (EIA, 2013; EPBD (Implementing the Energy Performance Building Directive), 2010).

In Brussels-Capital Region, government amended decrees on 5th May 2011 for passive energy building (PEB) requirements for all new constructions. According to this regulation standard for energy performance and interior climate of buildings, made comparable to the passive house for new buildings constructed by 2015 and onwards (EIA, 2013; EPBD (Implementing the Energy Performance Building Directive), 2010). Starting 1st January 2015, individual Housing PEB units have: a primary energy consumption for heating, domestic hot water and electrical appliances below $45 \mathrm{~kW} \mathrm{~h} / \mathrm{m}^{2} /$ year, air tightness at 50 Pa below $0.6 / \mathrm{h}$, a net heating need below $15 \mathrm{~kW} \mathrm{~h} / \mathrm{m}^{2} /$ year, an overheating temperature that can only exceed $25{ }^{\circ} \mathrm{C}$ for $5 \%$ of the time throughout the year (EIA, 2013; EPBD (Implementing the Energy Performance Building Directive), 2010). Brussels government has approved 2013 subsidy system making it more wide spread and simplified. For roof insulation thickness corresponding to passive standard and for triple glazing it is planned to provide subsidy at the rate of $10 \mathrm{EUR} / \mathrm{m}^{2}$ and $30 \mathrm{EUR} / \mathrm{m}^{2}$, respectively. For renovation of existing building to attain passive/low energy standard subsidy has been increased by $30 \mathrm{EUR} / \mathrm{m}^{2}$ and for boiler renovation in collective housing an additional bonus of $20 \%$ on subsidies has been planned (EIA, 2013; EPBD (Implementing the Energy Performance Building Directive), 2010).

Walloon government since 2002 provides subsidies and loans for improving energy efficiency of existing buildings. Walloon region Menages à Bas Revenus (MEBAR) programme subsidizes low income households to improve the insulation, the heating installation and/or energy performance of the windows of their homes (EIA, 2013; EPBD (Implementing the Energy Performance Building Directive), 2010). The region set up two separate funds one to cover municipal, provincial, regional buildings and another one to cover schools and hospitals. The region also provides $70 \%$ subsidy to municipalities for the replacement of inefficient public lighting (EIA, 2013; EPBD (Implementing the Energy Performance Building Directive), 2010). In 2008, regional government encouraged installation of photovoltaic systems in households, small enterprises and self-employed workers by making them eligible to receive grants of $20 \%$ of the investment (EIA, 2013; EPBD (Implementing the Energy Performance Building Directive), 2010).

\section{Methodology}

The objective of the study is to analyse the existing residential building stock of Liege city based on different parameters (buildings age, structures, type of heating system, type of fuel used, built-up area, adjacency, insulation of roofs and walls and energy consumption) and to identify the areas which needs to be addressed to improve the energy efficiency of the buildings. This study focussed on the building stock which was built before 1945 . All these buildings are of historical importance for the society. Interestingly these buildings are still being occupied so it becomes important to adopt a holistic approach to analyse these buildings from energy perspective. Fig. 4 shows the flowchart of the 


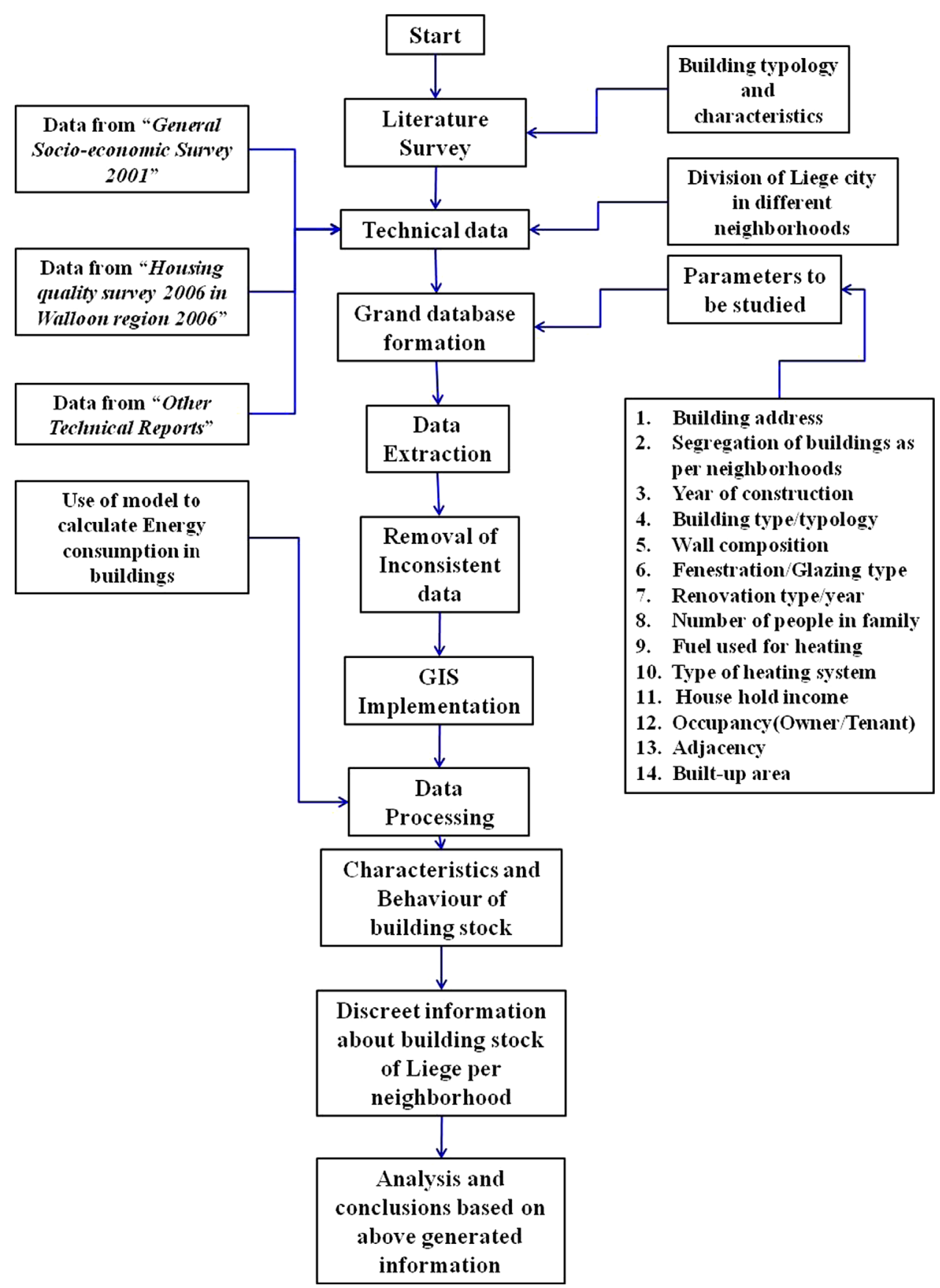

Fig. 4. Flowchart of the methodology.

methodology followed to analyse the energy efficiency initiatives in this study. The following two databases are used to generate discrete information about the existing building stock for each neighbourhood/municipality. The first one is the 'General Socioeconomic survey 2001' and other one is the 'Housing quality survey 2006 in Walloon region'. Out of these two databases, the General socio-economic survey 2001 is wide spread and covers the entire Belgium. In this survey, the occupants of the houses were asked to fill a detailed questionnaire. The housing quality survey has been carried out by experts and confined to Walloon region only. So there are certain advantages and limitations associated with using these databases. Building data for the Liege city are extracted from these databases. Total sample size from "General economic Survey" for Liege building stock is 58,738 and distribution of this is presented in different age groups. In case of "Housing quality survey 2006 in Walloon Region" sample size of Liege buildings is 476 . To draw conclusions from the analysis these two data base and data from other reports are used. Before carrying out the analysis, inconsistent information exists in the extracted data base has been removed. Fig. 5 represents the different neighbourhoods of Liege. Liege is a major city and third most populous city of Belgium and is the economic capital of Walloon region. It is also known for its steel industry, the historic backbone of Walloon region. The city is situated in the valley of the Meuse river. These two factors has played major role in the growth and development of the city as well as the building sector over the ages. The entire building stock of Liege is divided into 27 neighbourhoods. This analysis lead to discrete information about 

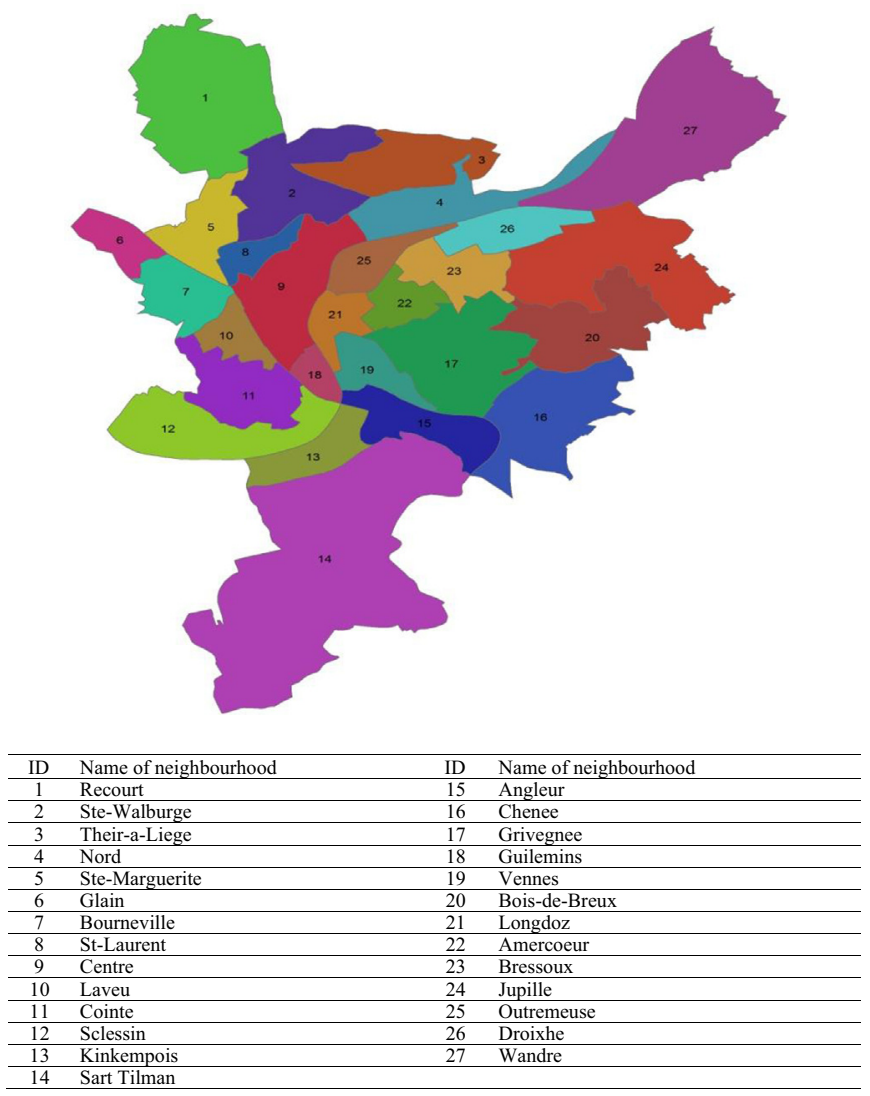

Fig. 5. Different neighbourhoods of Liege City.

Table 2

Number of houses and growth rate in Belgium (European Parliament and Council, 2003; EAS, 2011; Georgiadu et al., 2012).

\begin{tabular}{lll}
\hline Year & Number of dwellings (millions) & Growth rate (\%) \\
\hline 1981 & 3.6 & - \\
1991 & 3.7 & 4.1 \\
2001 & 4.1 & 9.0 \\
2008 & 4.3 & 4.5 \\
\hline
\end{tabular}

building stock in 27 neighbourhoods based on above mentioned parameters. ArcGIS Version 9 software has been used to plot the spatial distribution over the map of Liege.

\section{Analysis of the building stock}

\subsection{Buildings of Belgium}

There were 4.3 million dwellings in Belgium in the year 2008 . Most of the recent studies on building have concluded that building stock in Belgium and in particular in Walloon region are relatively old. Demolition and growth rate is also very slow i.e. $0.075 \%$ and $1 \%$, respectively (Meinel et al., 2009; Verhoeven, 2009). Table 2 presents the number of buildings and growth rate from 1981 to 2008 for the country. It can be observed from Table 2, that there was a substantial growth during the year 1991 to 2001. However, at present, the rate is mere $4.5 \%$ which is half of the growth rate during the period 1991 to 2001 (Meinel et al., 2009;

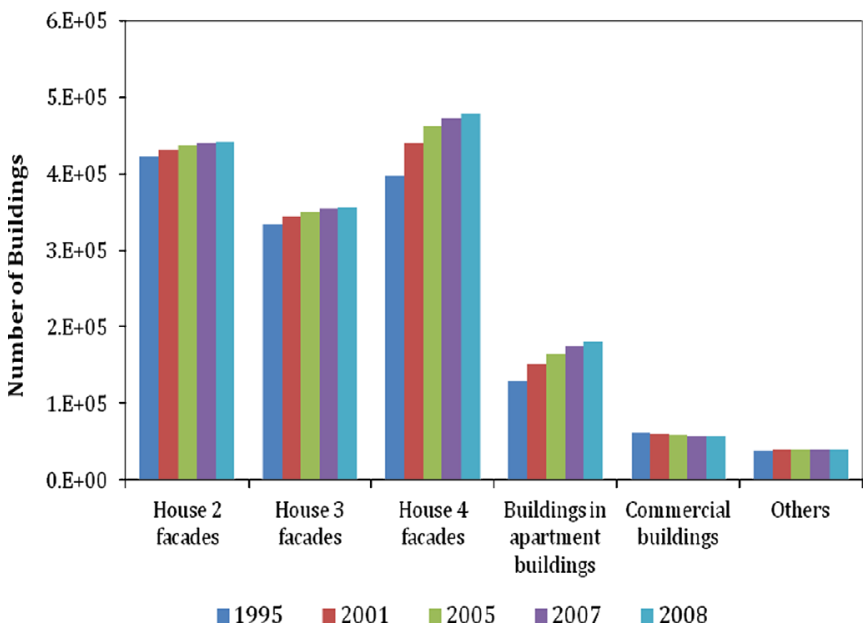

Fig. 6. Different types of buildings in Walloon region (European Parliament and Council, 2003)

Verhoeven, 2009). Urban areas have highest density of buildings but the maximum increase is occurring in sub-urban region. Distribution of buildings according to different age group (year of construction) shows a distinct pattern across the three regions of Belgium. In most of the municipalities of the Walloon region, more than $40 \%$ of the building stock is built before 1945 (Meinel et al., 2009; Verhoeven, 2009). In Brussels capital region and Flanders region, majority of houses are constructed between the years 1946 to 1980. It is also observed that Flanders region gather most of the newly constructed dwellings which has resulted in the growth of residential area from $227 \mathrm{~m}^{2}$ per inhabitant in 1990 to $278 \mathrm{~m}^{2}$ per inhabitant in 2002 (Meinel et al., 2009; Verhoeven, 2009). Out of the total number of houses in the year 2008, single family housing constitutes $81 \%$ and apartment buildings constitutes around 19\% respectively. Fig. 6 represents the number of houses with different facades. The houses with four facades represent detached houses and houses with two and three facades represent the semi-detached houses (ICEDD (Institut de Conseil et d'Etudes en Developpement Durable ASBL), 2007).

\subsection{Buildings structures of Liege}

The building structure is a continuous evolving process to address the climate specific requirements and as well as represents the social and cultural setup of the region (Kohler and Hassler, 2002; Dascalaki et al., 2010, 2011; Tambach et al., 2010; Theodoridou et al., 2011a,b). In recent years, energy requirements during the construction of the buildings and later stage the operation have become a serious concern for many countries. The rising energy consumption in the buildings has forced the architects and policy makers to look for alternatives. The thermal as well as energy performance study of any building provides an insight and understanding of the complex functioning of building and its possible effects on the environment (Dascalaki et al., 2010, 2011; Tambach et al., 2010; Theodoridou et al., 2011a,b). Thermal as well as energy performance of a building mainly influence by the following factors.

\footnotetext{
- Local/regional climate

- Building envelope, construction materials and year of construction (age)

- Building energy systems

- Building operation and maintenance

- Occupants activity and thermal expectations

- Indoor environmental quality and its control
} 
Hence, it is necessary to apply integrated approach by considering the above parameters to achieve the optimum building design. It is also important to understand the functionality of the building. The most conventional approach towards this issue is to define the typology of the buildings and associate different energy related characteristics (functionality, year of construction, built-up area, wall composition and thickness, window to wall ratio and occupancy level). The buildings characteristic can be divided based on the above parameters. Building stock of Liege is divided into nine typologies. For selecting typology of buildings in Liege city a study related to the typology of buildings of Liege "Typologie du logement Liege, Institut Wallon, Bilan energetique de la ville de Liege, 1985" is used. It is indeed considered that building typologies in dense, urban environments like Liege are somehow specific when compared to building typologies designed to address the building stock of the entire Walloon region (Massart and De Herde, 2010; Trachte, De Herde, 2010), which will cover, by nature, rural and urban environments. However, in this study the buildings which are constructed before 1945, falls under five different typologies. In next section, distinct features of all these five typologies are discussed in details.

\subsubsection{Maison Modeste (modest house)}

This type of houses are built in the second half of the 19th century and early 20th century and located primarily in the industrial suburb of Liege. Fig. 7A and B represents this type of typology. These houses are constructed along the street and in groups (have shared facade on two sides). These houses also have adjoining gable and the width of the house is 4 to $5 \mathrm{~m}$. The house

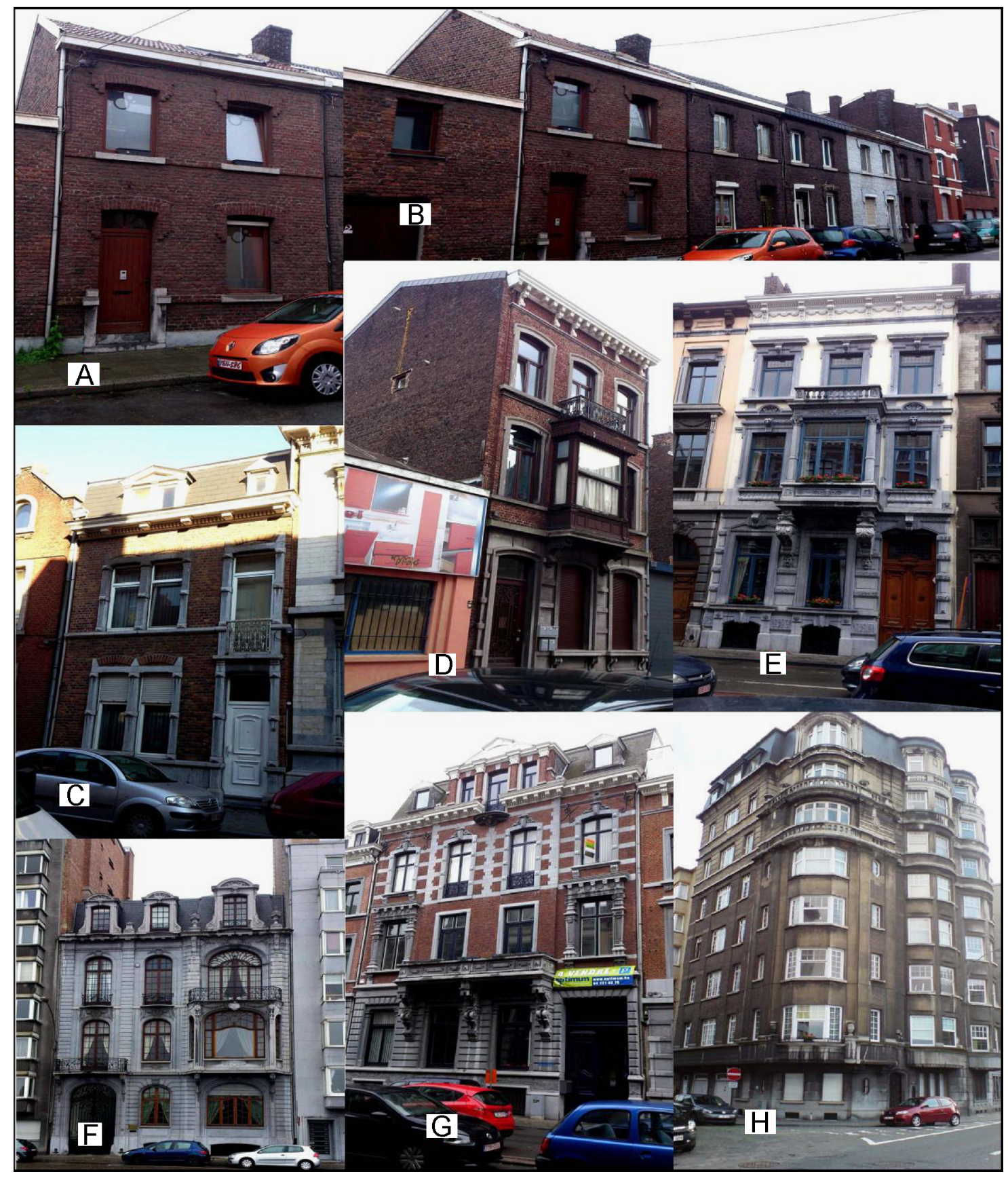

Fig. 7. Building typology of Liege. 
is generally constructed in two floors. It has pitched roof $\left( \pm 45^{\circ}\right)$ and made up of tiles. Windows and doors are of elongated shape. Facades are made up of brick masonry with overhangs.

\subsubsection{Maison Moyenne (average house)}

Maison Moyenne types of house presented in Fig. 7C. These types of houses are constructed at the end of the 19th century and in the beginning of the 20th century. These houses are constructed in the urban area along the street and in groups (have shared façade on two sides). These houses also have adjoining gable and the width of the house is 5 to $6 \mathrm{~m}$. This type of houses has pitched roof with a provision to allow skylight to the interiors. Windows and doors of this type of houses are wider than Maison Modeste. The distinct feature of this typology is the projecting cornice and appearance of the balcony on the second floor. Front facade is made up of brick and decorated with decorative stone or projections or coloured bricks.

\subsubsection{Maison De Maitre (house)}

The houses of this typology are constructed at the end of the 19th century and beginning of the 20th century. These types of houses are constructed along the new roads that are constructed in late 19th century. These houses also have adjacent gable and the width of the house is from 7 to $12 \mathrm{~m}$. These houses consist of 2 to 4 floors with significant height. Windows and doors are large with prominent and decorated cornice. These houses have loggia on first floor and balcony on the second floor. Roof of these types of houses have two or more slopes with gabled dormer roof. This typology is represented in Fig. 7D and E. Facade of the house is made up of brick, stone and plaster. The rear roof of the house is flat type.

\subsubsection{Maison Historique (historic house)}

Houses of this typology are built in 18th and 19th century. These houses are located in the centre and outskirts of Liege city (Bressoux and Jupille). Fig. 7F and G represents the houses of this typology. These houses have timbered adjoining gables. The span of the house varies. Front span is from 3 to $7 \mathrm{~m}$. It is constructed in detached and semi-detached form. Windows and doors of this type of houses are tall and narrow. Facade is made up of carved stone frame (columns and lintels). This typology of house has got pitched roof with two slopes $\left( \pm 50^{\circ}\right)$ and made up of tiles (slates).

\subsubsection{Maison apartments (apartment house)}

Fig. $7 \mathrm{H}$ represents this kind of buildings typology. These types of buildings are constructed from 1930 and to till date. These buildings are mainly constructed along the river Meuse (Liege city is inhibited in both bank of this river) and also along the main streets of the city (grand boulevards). These building are generally multilevel ranging from 4 to 20 storeys and structure is made up of reinforced concrete. These have flat roofs and facade is fitted with solar glass (double glazing).

\section{Building characteristic analysis}

In this study, General Socio-economic survey 2001 of Belgium and Housing quality survey 2006 for Walloon region has been used for the analysis of the building stock of Liege. These two databases have both advantages and limitations. General Socioeconomic survey 2001 covers entire Belgium and statistically provides good trend and approximation. However, Housing quality survey 2006 for Walloon covers relatively smaller sample size (total 6000 houses is being covered in the survey). From the General Socio-economic survey 2001, the information related to the building heating system and the building construction (age) year, types of fuel used in heating system, income pattern of the occupants, built-up area etc. are obtained. Similar kinds of information are also collected from Housing quality survey 2006 for Walloon region. However, more specific information like insulation details, glazing etc is inferior in General Socio-economic survey 2001 as compared to that of Housing quality survey 2006 for Walloon region database. The findings reported in this study about the characteristics of building stock of Liege are supported by both these databases. Here, both databases supplement the information required for the analysis.

Fig. 8 represents the distribution of number of buildings from 1863 to 2009. In each age group, all the buildings built-up areas are considered for this study. It is evident from Fig. 8, that the number of buildings reached its peak between the years from 1920 to 1944 . This growth can be attributed to the economic and rapid industrial growth that took place after First World War supporting the growing demand in the housing sector. It can also be observed that after 1944, there is a gradual decrease in the number of buildings constructed and it continues till now. The most noticeable observation is that there is a sharp fall in the number of buildings constructed between the years 1965 to 1984. The reason behind this fall in numbers can be attributed to the oil embargo and eventually the economic slowdown that happened in 1970s. It also needs to analyse the growth trend of this sector according to built-up area $\left(\mathrm{m}^{2}\right)$ across the different age groups. Fig. 9

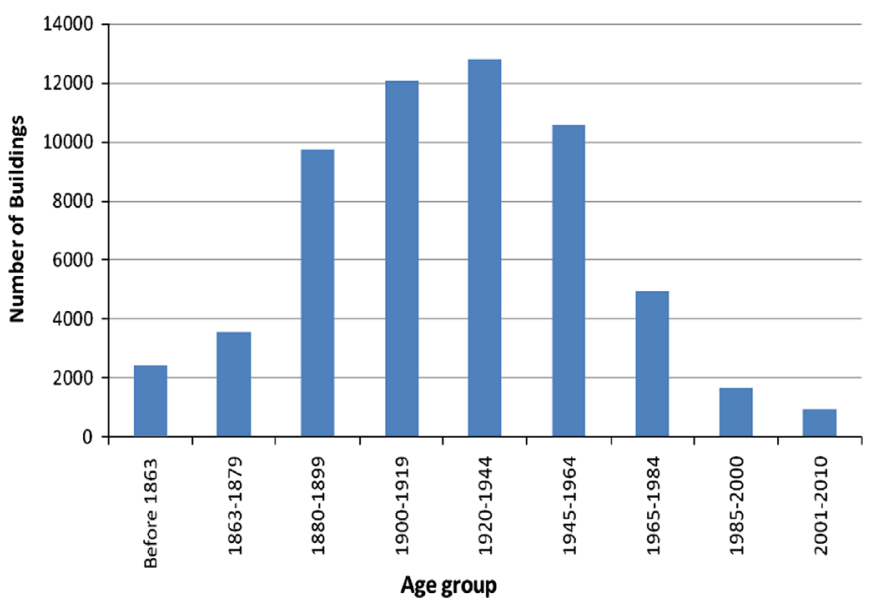

Fig. 8. Number of buildings in different year groups in Liege.

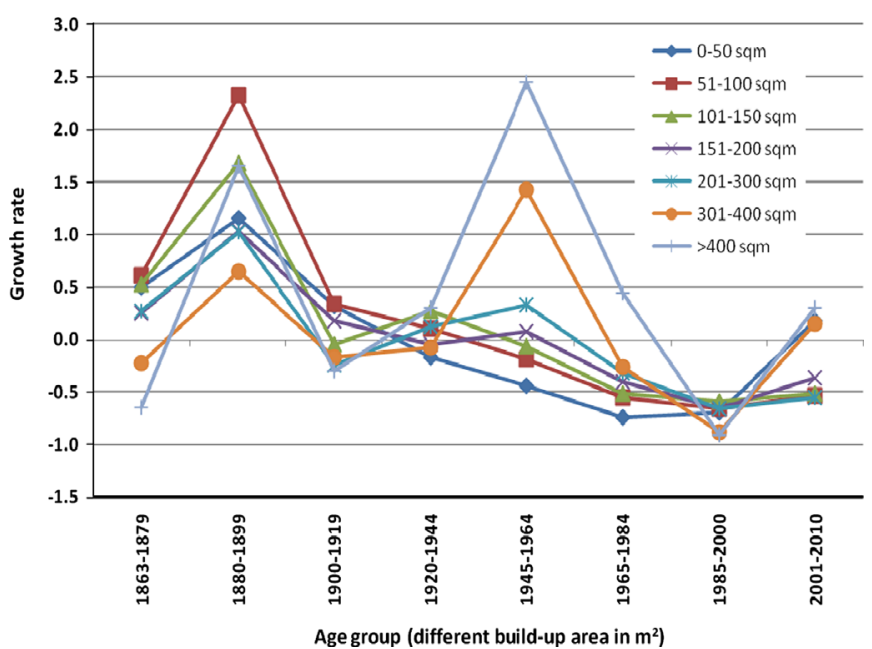

Fig. 9. Growth rate of building of different built-up area in different age groups. 
represents the growth rate of buildings of different built-up area in different age groups. It can be concluded from Fig. 9 that before First World War, rapid industrial activity has fuelled the growth in the building sector across all the built-up area groups. Almost identical trend is again observed after Second World War and before the first oil embargo. The growth in building sector of Liege is in negative trajectory after oil embargo until recent times. It turns to positive trajectory in 2001-2010 but only few built-up

Table 3

Distribution of building stock of Liege according to different construction year.

\begin{tabular}{|c|c|c|c|c|c|c|c|c|c|}
\hline \multirow[t]{2}{*}{ ID } & \multirow[t]{2}{*}{ Neighbourhood } & \multicolumn{6}{|c|}{ Building construction period } & \multirow[t]{2}{*}{ Total buildings } & \multirow{2}{*}{$\begin{array}{l}\text { Share of building } \\
\text { before } 1945(\%)\end{array}$} \\
\hline & & Before 1863 & 1863 to 1880 & 1880 to 1900 & 1900 to 1920 & 1920 to 1945 & 1945 Onwards & & \\
\hline 1 & Recourt & 25 & 21 & 62 & 127 & 292 & 1975 & 2502 & 21.06 \\
\hline 2 & Ste-Walburge & 18 & 86 & 384 & 729 & 1163 & 1075 & 3455 & 68.89 \\
\hline 3 & Their-a-Liege & 21 & 24 & 152 & 343 & 599 & 797 & 1936 & 58.83 \\
\hline 4 & Nord & 66 & 216 & 1138 & 745 & 278 & 243 & 2686 & 90.95 \\
\hline 5 & Ste-Marguerite & 83 & 76 & 347 & 582 & 663 & 371 & 2122 & 82.52 \\
\hline 6 & Glain & 22 & 30 & 67 & 170 & 58 & 184 & 531 & 65.35 \\
\hline 7 & Bourneville & 34 & 62 & 388 & 423 & 403 & 622 & 1932 & 67.81 \\
\hline 8 & St-Laurent & 224 & 291 & 431 & 348 & 111 & 127 & 1532 & 91.71 \\
\hline 9 & Centre & 1147 & 910 & 1269 & 426 & 167 & 508 & 4427 & 88.52 \\
\hline 10 & Laveu & 9 & 65 & 457 & 693 & 476 & 257 & 1957 & 86.87 \\
\hline 11 & Cointe & 17 & 27 & 160 & 346 & 388 & 970 & 1908 & 49.16 \\
\hline 12 & Sclessin & 9 & 67 & 220 & 575 & 368 & 482 & 1721 & 71.99 \\
\hline 13 & Kinkempois & 2 & 43 & 218 & 230 & 217 & 228 & 938 & 75.69 \\
\hline 14 & Sart Tilman & 10 & 31 & 21 & 44 & 93 & 725 & 924 & 21.54 \\
\hline 15 & Angleur & 6 & 66 & 398 & 368 & 466 & 536 & 1840 & 70.87 \\
\hline 16 & Chenee & 124 & 218 & 611 & 1049 & 664 & 1038 & 3704 & 71.98 \\
\hline 17 & Grivegnee & 59 & 214 & 385 & 605 & 2069 & 2377 & 5709 & 58.36 \\
\hline 18 & Guilemins & 0 & 6 & 241 & 220 & 48 & 212 & 727 & 70.84 \\
\hline 19 & Vennes & 2 & 12 & 77 & 320 & 1064 & 137 & 1612 & 91.50 \\
\hline 20 & Bois-de-Breux & 8 & 10 & 92 & 213 & 677 & 1325 & 2325 & 43.01 \\
\hline 21 & Longdoz & 6 & 294 & 276 & 151 & 106 & 157 & 990 & 84.14 \\
\hline 22 & Amercoeur & 26 & 213 & 640 & 501 & 485 & 287 & 2152 & 86.66 \\
\hline 23 & Bressoux & 1 & 38 & 550 & 1266 & 651 & 532 & 3038 & 82.49 \\
\hline 24 & Jupille & 49 & 117 & 303 & 797 & 658 & 1682 & 3606 & 53.36 \\
\hline 25 & Outremeuse & 314 & 174 & 479 & 490 & 172 & 199 & 1828 & 89.11 \\
\hline 26 & Droixhe & 0 & 0 & 3 & 39 & 73 & 168 & 283 & 40.64 \\
\hline 27 & Wandre & 133 & 244 & 363 & 288 & 411 & 914 & 2353 & 61.16 \\
\hline
\end{tabular}

Table 4

Distribution of buildings built-up area in Liege.

\begin{tabular}{|c|c|c|c|c|c|c|c|c|}
\hline \multirow[t]{2}{*}{ ID } & \multirow[t]{2}{*}{ Neighbourhood } & \multicolumn{7}{|c|}{ Buildings built-up area $\left(\mathrm{m}^{2}\right)(\%)$} \\
\hline & & $0-50$ & $51-100$ & $101-150$ & $151-200$ & $201-300$ & $301-400$ & $>401$ \\
\hline 1 & Recourt & 6.4 & 57.3 & 23.3 & 7.4 & 3.8 & 0.8 & 0.9 \\
\hline 2 & Ste-Walburge & 13.1 & 65.0 & 14.0 & 4.4 & 2.3 & 0.4 & 0.8 \\
\hline 3 & Their-a-Liege & 22.1 & 58.5 & 14.1 & 3.5 & 1.2 & 0.5 & 0.2 \\
\hline 4 & Nord & 22.6 & 48.7 & 18.1 & 4.6 & 3.7 & 0.7 & 1.6 \\
\hline 5 & Ste-Marguerite & 22.9 & 60.7 & 11.0 & 2.5 & 1.9 & 0.4 & 0.6 \\
\hline 6 & Glain & 7.9 & 55.2 & 26.0 & 7.9 & 1.7 & 1.3 & 0.0 \\
\hline 7 & Bourneville & 18.1 & 58.5 & 15.4 & 4.8 & 2.0 & 0.4 & 0.7 \\
\hline 8 & St-Laurent & 16.4 & 56.3 & 16.8 & 4.4 & 4.0 & 1.4 & 0.7 \\
\hline 9 & Centre & 15.2 & 37.7 & 23.5 & 8.9 & 6.9 & 3.5 & 4.4 \\
\hline 10 & Laveu & 19.1 & 65.2 & 10.8 & 2.4 & 1.7 & 0.3 & 0.6 \\
\hline 11 & Cointe & 12.2 & 61.8 & 15.8 & 6.3 & 3.0 & 0.4 & 0.5 \\
\hline 12 & Sclessin & 21.2 & 55.6 & 13.2 & 4.6 & 2.2 & 0.8 & 2.4 \\
\hline 13 & Kinkempois & 17.5 & 63.6 & 12.0 & 4.6 & 1.4 & 0.9 & 0.0 \\
\hline 14 & Sart Tilman & 5.6 & 37.1 & 29.3 & 14.2 & 10.8 & 1.5 & 1.4 \\
\hline 15 & Angleur & 22.7 & 62.4 & 10.3 & 2.0 & 1.3 & 0.6 & 0.7 \\
\hline 16 & Chenee & 29.9 & 52.5 & 11.2 & 3.7 & 1.7 & 0.5 & 0.6 \\
\hline 17 & Grivegnee & 19.8 & 63.9 & 10.5 & 2.9 & 1.5 & 0.5 & 0.8 \\
\hline 18 & Guilemins & 2.8 & 47.0 & 27.1 & 7.4 & 6.7 & 3.4 & 5.5 \\
\hline 19 & Vennes & 8.0 & 53.2 & 23.0 & 8.3 & 4.1 & 1.4 & 2.0 \\
\hline 20 & Bois-de-Breux & 15.5 & 55.8 & 18.6 & 5.4 & 2.5 & 1.5 & 0.7 \\
\hline 21 & Longdoz & 12.8 & 44.8 & 18.3 & 7.3 & 6.3 & 3.3 & 7.2 \\
\hline 22 & Amercoeur & 20.1 & 61.8 & 10.9 & 3.4 & 2.1 & 0.9 & 0.7 \\
\hline 23 & Bressoux & 27.5 & 54.2 & 11.0 & 3.4 & 2.3 & 0.7 & 0.9 \\
\hline 24 & Jupille & 20.0 & 52.8 & 18.6 & 5.7 & 2.3 & 0.4 & 0.2 \\
\hline 25 & Outremeuse & 15.3 & 48.4 & 19.0 & 6.3 & 4.9 & 2.8 & 3.3 \\
\hline 26 & Droixhe & 5.7 & 54.1 & 18.4 & 9.2 & 4.6 & 1.4 & 6.7 \\
\hline 27 & Wandre & 19.8 & 54.1 & 18.9 & 4.8 & 1.9 & 0.3 & 0.3 \\
\hline
\end{tabular}


area groups $\left(0-50 \mathrm{~m}^{2}, 301-400 \mathrm{~m}^{2}\right.$ and greater than $\left.400 \mathrm{~m}^{2}\right)$ has shown significant improvement in growth rate (per year). This trend is observed because the economic slowdown leads to the drastic change in socio-economic status and eventually leading to increase in single family houses. Over last 10 years number of private households is growing faster than the population. This is because numbers of large buildings have been converted to single family homes. There is a gradual decrease in the size of the households (built-up area) and also number of people staying under same roof between the year 1995 to 2007 (Meinel et al., 2009).

Table 3 represents the distribution of building stock of Liege according to different construction years across 27 neighbourhoods. It is evident from Table 3 that approximately $68.33 \%$ of the building stock is pre-1945 in the Liege city. It also can be concluded that Centre and Outremeuse neighbourhoods has high density of old buildings which were constructed before 1920 . These two neighbourhoods are situated on either bank of river Meuse. The Centre neighbourhood acts mainly as an economic hub and Outremeuse as residential area. Table 4 represents the distribution of houses in all the neighbourhoods according to the built-up area. It is found that about 55\% of household have built-up area lies between 51 and $100 \mathrm{~m}^{2}$ and $16 \%$ and $17 \%$ for built-up area of $0-50 \mathrm{~m}^{2}$ and $101-150 \mathrm{~m}^{2}$, respectively. The maximum density of the house with built-up area of 51-100 $\mathrm{m}^{2}$ and $0-50 \mathrm{~m}^{2}$ lies in Centre neighbourhood and in the industrial belt of Liege. This trend is observed because in Centre this is being driven by the high economic value of space but in industrial belt mainly the people (of average revenue) who work in steel industry have their houses. It is also important to note that about $55 \%$ of houses are generally used as rented accommodation and only $41 \%$ of houses are being used by the owners in Liege (based on housing quality survey data). This trend also justified the reason for low thermal performance of the houses. As the tenant has limited or almost no choice to improve the thermal performance of houses and on the other hand it gets least importance from the owner as he/she does not stay in the house and the energy bill are being paid by the tenant.

\section{Building energy performance analysis}

Different parameters of buildings of Liege and the properties that affect the energy performance of the buildings are discussed in this section. It is found from Fig. 10 that majority of the buildings are constructed using terracotta bricks, stone, concrete, wood and clay tiles in different proportions and combinations. These building materials lead to massive structure and with no insulation to external walls and roofs, made these buildings highly energy intensive. It can be observed from Fig. 10 that $67 \%$ of buildings have massive walls and remaining 33\% have composite walls. Massive walls are again broadly divided into three types (i) terracotta brick (65\%), (ii) concrete (8\%) and (iii) stone (26\%). The composite walls are divided broadly into two types (i) brick composite and (ii) concrete composite. The compositions of floors of these houses are reinforced concrete slabs (55\%), metal beam and brick arches (31.3\%) and wood (13.6\%) respectively. However, the compositions of intermediate floors are very distinct and based on the local climate requirements. Floor of $81 \%$ of houses is made up of wood, $14.4 \%$ is made up of reinforced concrete slabs and $4.6 \%$ is made up of metal beams and brick arches. It is also found that approximately $80.5 \%$ of buildings do not have insulated external walls. Only $15 \%$ have complete wall insulation and $4.5 \%$ have partial wall insulation. It is observed that windows of $60 \%$ of buildings are fully insulated with double glazing, 18\% have partially insulated glazing and 22\% does not have any insulated glazing. The reason behind this high percentage of insulation level in glazing area is that

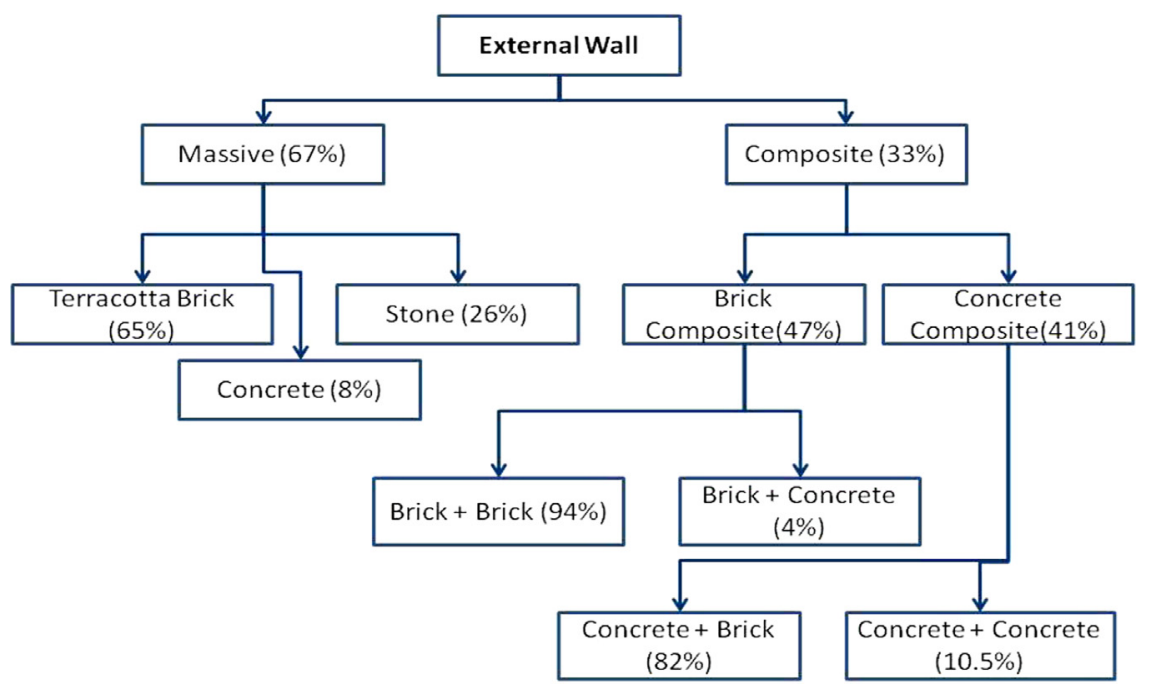

Fig. 10. Composition of external walls of the houses constructed before 1945 .

Table 5

Properties of various buildings components that affect the thermal performance (France-Laure et al., 2011).

\begin{tabular}{|c|c|c|c|c|c|c|c|}
\hline \multirow[t]{2}{*}{ Age of buildings } & \multicolumn{5}{|c|}{ Overall heat transfer coefficient $\left(\mathrm{w} / \mathrm{m}^{2} \mathrm{~K}\right)$} & \multirow{2}{*}{$\begin{array}{l}\text { Ventilation } \\
\text { (air change per hour) }\end{array}$} & \multirow{2}{*}{$\begin{array}{l}\text { Glazing } \\
\text { area }(\%\end{array}$} \\
\hline & Roof & Glazing & External wall & Floor & Intermediate floor & & \\
\hline Before 1945 & 1.61 & 3.29 & 2.2 & 1.92 & 4.45 & 0.6 & 30 \\
\hline $1946-1970$ & 1.44 & 3.33 & 1.4 & 1.45 & 3.93 & 0.6 & 35 \\
\hline 1971-1986 & 0.97 & 3.09 & 0.8 & 2.41 & 3.85 & 0.6 & 35 \\
\hline 1987-1996 & 0.91 & 2.59 & 0.5 & 0.44 & 3.73 & 0.6 & 40 \\
\hline 1997-2006 & 0.72 & 2.40 & 0.5 & 0.41 & 3.66 & 0.6 & 40 \\
\hline
\end{tabular}


Table 6

Heating energy consumption in the buildings.

\begin{tabular}{lll}
\hline Year of construction & $\begin{array}{l}\text { Energy consumption } \\
\left(\mathrm{kW} \mathrm{h} / \mathrm{m}^{2} \text {-year }\right)\end{array}$ & $\begin{array}{l}\text { Standard deviation } \\
\left(\mathrm{kW} \mathrm{h} / \mathrm{m}^{2} \text {-year }\right)\end{array}$ \\
\hline Before 1863 & 382.8 & 98.8 \\
$1863-1879$ & 354.9 & 90.0 \\
$1880-1899$ & 326.3 & 80.3 \\
$1900-1919$ & 312.3 & 73.4 \\
$1920-1944$ & 323.0 & 74.9 \\
$1945-1964$ & 250.1 & 54.3 \\
$1965-1984$ & 224.9 & 56.8 \\
$1985-2000$ & 136.2 & 33.4 \\
$2001-2010$ & 127.0 & 29.6 \\
\hline
\end{tabular}

these building went through renovation during the years 1980 to 1990. There is also tax incentive towards renovating windows and more over they are relatively easy to replace at low cost in comparison to the insulation of walls and roofs. The buildings those are constructed before 1945 in the city, 50\% of them have no roof insulation. Only $5 \%$ of buildings are partially insulated and $45 \%$ of the building has complete roof insulation. It is also interesting to note that $96.5 \%$ of houses have pitched roof.

Table 5 represents the overall heat transfer coefficient $(U)$ of different building components like external walls, glazing, floor and intermediate floor. It can be observed from Table 5 that for new construction there is a considerable improvement in the $U$ values of building components over the years (France-Laure et al., 2011). The same fact has also been supported by the decreasing heating energy requirement for the buildings over the period of time (Table 6) (Dujardin et al., 2010, 2013; Walloon Government, 2007). Table 6 represents the heating energy consumption per year of the building stock over the years. This heating energy consumption of the buildings are calculated based on a model which takes into account the physical parameters of the wall, roof, insulation level, ventilation rate, internal gains, efficiency of heating system, solar insolation and shading (Dujardin et al., 2010, 2013; Walloon Government, 2007). The heating energy consumption per year varies from $382.8 \mathrm{~kW} \mathrm{~h} / \mathrm{m}^{2}$ (for building constructed before 1863) to $127.0 \mathrm{~kW} \mathrm{~h} / \mathrm{m}^{2}$ (building constructed between 2001 and 2012). This heating energy consumption gradually decreases when we move towards the more recently constructed buildings. Standard deviation in the heating energy consumption per year for the building constructed before 1863 is high because the building that are located in dense urban area have shared facade and those are in rural settings are detached (Fig. 7B). In the Walloon region, the average heating energy consumption per year of the building stock that are constructed before 1945 is $407.8 \mathrm{~kW} \mathrm{~h} / \mathrm{m}^{2}$ and for building that are constructed after 1996, it is $172 \mathrm{~kW} \mathrm{~h} / \mathrm{m}^{2}$. Prominent reason behind this difference is the standard degree-days. Standard degree days value for Liege is significantly lower (1987.1) than the Walloon region average (2380). It is also found from the data base that in Walloon region the external walls of $91 \%$ and roof of $78 \%$ of houses are not insulated. It is observed from the temperature profile of Liege that most of the time of the year heating is required and the same fact is being supported by the relatively high heating degree days of Liege (Table 6) (Dujardin et al., 2010, 2013; Walloon Government, 2007).

It is also found that the buildings that are in city centre have most shared facade or building stock with high adjacency. Fig. 11 represents the distribution of buildings which have adjacency more than $35 \%$. It means that these buildings share common wall on at least two sides. This is justified that due to high cost of space, people forced to go for compact housing. It is observed from Fig. 11 that in city centre (ID 9) and the neighbourhoods adjoining city centre having high density of buildings which have high adjacency (more than 35\%). As we move away from the city centre, it is found
Share ( in \%) of Buildings With more than $35 \%$ of Shared Facad

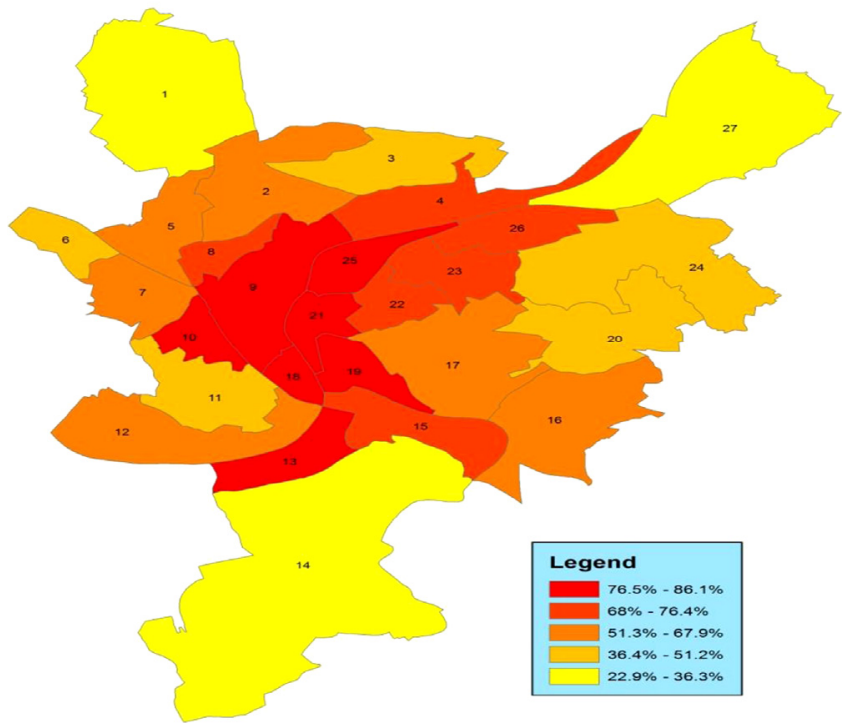

Fig. 11. Distribution of buildings with shared facade (more than 35\%).

that the density of shared facade houses decreases i.e. the density of detached houses increases. The houses with high revenue (high net worth occupants) are mostly located away from city centre. Since the owners of these houses can afford large built-up area and can also afford daily movement to their work place.

Heating energy consumption of building is largely dependent on type of heating system and fuel used. It can be concluded from Table 7 that $75 \%$ of Liege building stock has central heating system and remaining $25 \%$ have individual/local heating system. It is also observed that as we move close to centre, buildings with central heating system tends to increase. And as move away from centre to sub-urban region the density of individual heating system increases. The reason behind this is that the houses in sub-urban region have relatively high income and the occupants of these houses are willing to compromise with energy efficiency for aesthetic value. It is also observed that the installation of boilers of $39 \%$ central heating are more than 5 years and less than 15 years old and 35\% of boilers are more than 15 years old. Only $26 \%$ of boilers are less than 5 years old. So, it can be concluded that $74 \%$ of boilers need regular monitoring or renovation or may be replacement from the energy efficiency perspective. It is also found that about $75.5 \%$ of heating system uses natural gas (much cleaner fuel compared to coal, fuel oil and wood) and $22.8 \%$ use fuel oil. Very few heating system use coal (2\%) and electricity (2.4\%) respectively.

\section{Conclusions}

This study focuses on finding the characteristics of residential building stock of Liege and its neighbourhoods. Such a meso level analysis of building stock presents a clear picture of the parameters that affects the growth of building sector and its distribution in Liege city. It has been tried to broadly cover the wide spectrum of parameters that affects the building energy performance and growth rate over the period. From the analysis of the building stock in different age groups, it can be concluded that about $69 \%$ of buildings are relatively old and constructed before 1945. It is highlighted that these buildings were renovated in 1970-1980, but the renovation was confined to a change of simple glazing to double glazing because of less investment requirement and ease of replacement supported by government tax benefits. It is also observed that the growth trend in building sector as a whole is directly influenced by the economic 
Table 7

Distribution of heating system in the building stock of Liege.

\begin{tabular}{|c|c|c|c|c|c|}
\hline \multirow[t]{2}{*}{ ID } & \multirow[t]{2}{*}{ Neighbourhood } & \multicolumn{4}{|l|}{ Houses with (\%) } \\
\hline & & No central heating & Central heating & $\begin{array}{l}\text { Central heating for all houses } \\
\text { of same building }\end{array}$ & $\begin{array}{l}\text { Common central heating } \\
\text { for several building }\end{array}$ \\
\hline 1 & Recourt & 22.18 & 69.82 & 6.79 & 1.21 \\
\hline 2 & Ste-Walburge & 28.95 & 44.55 & 25.51 & 0.99 \\
\hline 3 & Their-a-Liege & 30.48 & 53.23 & 15.26 & 1.03 \\
\hline 4 & Nord & 14.29 & 30.99 & 45.96 & 8.76 \\
\hline 5 & Ste-Marguerite & 31.45 & 48.59 & 19.49 & 0.48 \\
\hline 6 & Glain & 38.72 & 54.06 & 6.82 & 0.41 \\
\hline 7 & Bourneville & 23.27 & 52.43 & 22.42 & 1.88 \\
\hline 8 & St-Laurent & 29 & 37.46 & 32.68 & 0.86 \\
\hline 9 & Centre & 13.98 & 34.30 & 50.29 & 1.43 \\
\hline 10 & Laveu & 8.07 & 75.80 & 9.77 & 6.37 \\
\hline 11 & Cointe & 25.06 & 64.97 & 9.61 & 6.37 \\
\hline 12 & Sclessin & 37.93 & 52.08 & 9.75 & 0.24 \\
\hline 13 & Kinkempois & 21.86 & 50.49 & 25.87 & 1.77 \\
\hline 14 & Sart Tilman & 25.30 & 63.07 & 10.19 & 1.44 \\
\hline 15 & Angleur & 24.50 & 44.92 & 30.19 & 0.39 \\
\hline 16 & Chenee & 38.80 & 46.97 & 13.40 & 0.82 \\
\hline 17 & Grivegnee & 27.18 & 66.48 & 5.94 & 0.40 \\
\hline 18 & Guilemins & 26.77 & 44.56 & 28.67 & 0.00 \\
\hline 19 & Vennes & 24.50 & 65.44 & 8.39 & 1.68 \\
\hline 20 & Bois-de-Breux & 28.87 & 62.34 & 8.52 & 0.27 \\
\hline 21 & Longdoz & 29.09 & 41.64 & 28.15 & 1.12 \\
\hline 22 & Amercoeur & 22.24 & 63.37 & 13.08 & 1.31 \\
\hline 23 & Bressoux & 38.01 & 56.45 & 5.49 & 0.05 \\
\hline 24 & Jupille & 36.11 & 58.77 & 4.82 & 0.29 \\
\hline 25 & Outremeuse & 21.93 & 30 & 46.15 & 1.92 \\
\hline 26 & Droixhe & 38.46 & 44.95 & 16.38 & 0.22 \\
\hline 27 & Wandre & 40.09 & 55.39 & 4.44 & 0.09 \\
\hline
\end{tabular}

activity of the region. The economic activity also put an increasing demand on houses of particular built-up area $\left(0-50 \mathrm{~m}^{2}, 51-100 \mathrm{~m}^{2}\right.$ and $301-400 \mathrm{~m}^{2}$ ) across the different age groups. The relative old age of building stock (of historical value) got minimum attention regarding overall insulation level of the building. This is because improving insulation through renovation is a complex and cost intensive process when the building is occupied and has a historical value. This is clearly seen in the analysis of the building stock that $80.5 \%$ and $50 \%$ of buildings do not have insulated external walls and roofs. In this area serious intervention of policy makers and researchers is needed. This conclusion is also supported by the high heating energy consumption in the houses that are constructed before 1945. It is found that buildings with high adjacency are concentrated in the city centre and so the central heating system. Central heating system is more efficient than individual heating system but the age of boilers is a cause of concern. It can be concluded that two third of boilers need immediate continuous monitoring or replacement to ensure efficient functioning. This study successfully identifies the specific areas which need further detailed study such as evaluating the comfort status in the existing building stock, a study on improvement of the insulation level in these houses and its effect on heating energy consumption as well as further cost benefit analysis. Analysis of building parameters that effect building energy efficiency has been done at micro level (neighbourhoods). It represents discrete information that can be useful for policy formulation. Future work in these areas based on the statistical analysis of EPBD certificates would generate sufficient information which would be helpful for policymakers both at the city and regional level.

\section{Acknowledgements}

The first author gratefully acknowledges the financial support received in the form of postdoctoral research grant from University of Liege to carry out the work. The authors would also like to acknowledge the help of Mr. Pierre-Emmanuel Pacot and Mr. Sebastien Dujardin in carrying out the analysis.

\section{References}

Anisimova, N., 2011. The capability to reduce primary energy demand in EU housing. Energy and Buildings 43 (10), 2747-2751.

Annunziata, E., Frey, M., Rizzi, F., 2013. Towards nearly zero-energy buildings: the state-of-art of national regulations in Europe. Energy , http://dx.doi.org/10.1016/j. energy.2012.11.049.

Attia, S., 2011. A case study for a zero impact building in Belgium: Mondo Solar2002. International Journal of Sustainable Building Technology and Urban Development 2, 137-142.

Balaras, C.A., Gaglia, A.G., Georgopoulou, E., Mirasgedis, S., Sarafidis, Y, Lalas, D.P. 2007. European residential buildings and empirical assessment of the Hellenic building stock, energy consumption, emissions and potential energy savings. Buildings and Environment 42 (3), 1298-1314.

Bartiaux, F., Vekemans, G. Gram-Hanseen, K., Maes, D., Cantaert, M., Spies, B. Desmedt, J., 2006. Socio-technical Factors Influencing Residential Energy Consumption (SEREC)-Part 1: Sustainable Production and Consumption Patterns, Scientific Support Plan for a Sustainable Development Policy (SPSD II) UCL. VITO and Danish Building Research Institute, Brussels, Belgium.

Bradley, P.E., Kohler, N., 2007. Methodology for the survival analysis of urban building stocks. Building Research and Information 35 (5), 529-542.

Carvalho, M., da, G., 2012. EU energy and climate change strategy. Energy 40 (1) 19-22.

Cyx, W., Renders, N., Van Holm, M., Verbeke, S., 2011.IEE TABULA-Typology Approach for Building Stock Energy Assessment. Technical Report. IEE Funded TABULA Project (Deliverable D6.7) 2012/TEM/R/47. August.

D'haeseleer, W., et al., 2009. PRIMES scenario analysis towards 2030 for Belgium. European Review of Energy Markets 3 (1). (pp number).

Dall'O', G., Galante, A., Torri, M., 2012. A methodology for the energy performance classification of residential building stock on an urban scale. Energy and Buildings 48 (5), 211-219.

Dascalaki, E.G., Droutsa, K.G., Balaras, C.A. Kontoyiannidis, S., 2011. Building typologies as a tool for assessing the energy performance of residential buildings-a case study for the Hellenic building stock. Energy and Buildings 43 (12), 3400-3409.

Dascalaki, E.G., Drousta, K., Gaglia, A.G., Kontoyiannidis, S., Balaras, C.A., 2010. Data collection and analysis of the building stock and its energy performance: an example for Hellenic buildings. Energy and Buildings. 42 (8), 1231-1237.

De Herde, A., Vermeir, G., Godart, M.F., Hanin, Y., Boland, Ph., Reiter, S., Rychtàrikovà, M., Castiau, E., Pons, T., Martin N., Meuris C., Moreau A., Xanthoulis, S. 
2009. Design and Renovation of Urban Public Spaces for Sustainable Cities Technical Report. Belgian Science Policy, Research Program Science for Sustainable Development, Final Report Phase 1,Brussels.

De Meester, T., 2010. Guide pour architectes de la rénovation basse énergie des logements en Belgique, Technical report. Politique scientifique fédérale, projet LEHR.

de Meester, T., Marique, AF., De Herde, A., Reiter, S., 2013. Impact of occupants behaviours on residential heating consumption for detached houses in a temperate climate in the northern part of Europe. Energy and Buildings 57, $313-323$.

Dujardin, S., France-Laure, L., Melin, E., Pirart, F., Teller, J., 2010. Structuring of the Territory to Meet the Objectives of Reducing Emissions of Greenhouse Gases, Colloque CPDT-La dimension territoriale des politiques énergétiques et de réduction des GIS, 8-9 Novembre, Liege, Belgium.

Dujardin, S., Marique, AF., Teller, J., 2013. Spatial planning as a driver of change in mobility and residential energy consumption. Energy and Buildings , http://dx. doi.org/10.1016/j.enbuild.2012.10.059.

EAS (Energy Annual Statistics), 2011. Energy Transport and Environment indicators Eurostat Pocketbooks Books, 2011 Edition, Publications Office of the European Communities, 2011, Luxembourg.

ECONOTEC, 2007. Energy efficiency policies and measures in Belgium 2006Monitoring of energy efficiency in EU 15 and Norway (ODYSSEE-MURE), Brussels, Belgium.

EIA, 2010. Annual Energy Outlook 2010-with Projections to 2035. DOE/EIA-0383 (2010), USA

EIA, 2013. Annual Energy Outlook 2013-with Projections to 2040. DOE/EIA-0383 (2013), USA.

Ekins, P., Lees, E., 2008. The impact of EU policies on energy use in and the evolution of the UK built environment. Energy Policy 36 (12), 4580-4583.

EPBD (Implementing the Energy Performance Building Directive), 2010. Featuring Country Reports 2010, Implementation of the EPBD in Belgium: Status in November 2010. Brussels, Belgium.

European Parliament and Council, 2003. Directive 2002/91/EC of the European Parliament and of the Council on the energy performance of buildings. Official Journal of the European Communities L 1/65, 4/1/2003.

European Parliament and Council, 2010a. Directive 2010/31/EU of the European Parliament and of the Council on the energy performance of buildings, Official Journal of the European Communities L 153/13, 18/6/2010.

European Parliament and Council, 2010b. Directive 2010/31/EU of the European Parliament and of the Council on the energy performance of buildings (Recast) Official Journal of the European Communities L 153/13, 18/6/2010.

Evrard, A., Branders, A., De Herde, A., 2011. Isolin, guide pour l'isolation par l'intérieur des murs existants en brique pleine. Technical Report, Service Public de Wallonie, DG04, Final Report.

Eurostat 2011, Energy, transport and environment indicators, European Commission, European Union publication, Luxemburg. ISSN 1725-4566.

Fracastoro, G.V., Serraino, M., 2011. A methodology for assessing the energy performance of large scale building stocks and possible applications. Energy and Buildings 43 (4), 844-852.

France-Laure, L., Jean-Marc, L., Teller, J., Dujardin, S., 2011. Urban Morphology and Energy Consumption of Residential Buildings to Meet the Objectives of Reducing Greenhouse Gas Emissions, The 18th International Seminar on Urban Morphology and the Post-Carbon City, 26-29 August, Concordia University, Montréal, Canada.

Georges, L., Massart, C., Van Moeseke, G., De Herde, A., 2012. Environmental and economic performance of heating systems for energy-efficient dwellings: case of passive and low-energy single-family houses. Energy Policy 40, 452-464.

Georgiadu, M.C., Hacking, T., Guthrie, P., 2012. A-conceptual-framework-for-futureproofing-the-energy-performance-of-buildings. Energy Policy. 47 (8), 145-155.

ICEDD (Institut de Conseil et d'Etudes en Development Durable ASBL), 2007. Bilan Energetique Wallon 2005 Consumptions du secteur lodgement 2005, rapport de recherche, Namur, Belgium.

IEA Annex 53, 2009. Energy conservation in Buildings and community systems, Total Energy Use in Buildings-Analysis and evaluation methods-2009. Japan.
IEA, 2007. Future Buildings Forum-2007, Vision and Research Roadmap for Future Sustainable Buildings and Communities, Espoo, Finland.

IEA, 2010. International Energy Agency. Energy Policies of IEA Countries-Belgium 2009 Review. OECD/IEA 2009, France.

Kohler, N., Hassler, U., 2002. The building stock as a research object. Building Research and Information 30 (4), 226-236.

Lechtenbohmer, S., Schuring, A., 2011. The potential for large-scale savings from insulating residential buildings in the EU. Energy Efficiency 4 (2), 257-270.

Massart, C., De Herde, A., 2010. Conception de maisons neuves durables. Technical Report, Service Public de Wallonie, DG04, Final Report.

Meinel, G., Hecht, R., Herold, H., 2009. Analyzing building stock using topographic maps and GIS. Building Research and Information. 37 (5-6), 468-482.

Mlecnic, E. et al., 2010. Low Energy Housing Retrofit (LEHR), Final Report, Belgian Science Policy (Programme to Stimulate Knowledge Transfer in Areas of Strategic Importance-TAP2), Brussels, 2010, 106

Ó. Broin, E., Mata, É., Göransson, A., Johnsson, F., 2013. The effect of improved efficiency on energy savings in EU-27 buildings Energy, 10.1016/j. energy.2013.01.016.

Panayiotou, G.P., Kalogirou, S.A., Florides, G.A., Maxoulis, C.N., Papadopoulos, A.M., Neophtou, M., Fokaides, P., Georgiou, G., Symeou, A., Georgakis, G., 2010. The characteristics and the energy behaviour of the residential building stock of Cyprus in view of Directive 2002/91/EC. Energy and Buildings 42 (11), 2083-2089.

Renard, F., Nourricier, S., Pietrantonio, M.D., Feldheim, V., 2008. Technical-Economic Analysis of the Cost-Effectiveness of Energy Saving Investments for Residential Buildings. Technical Report, Service Public de Wallonie, DG04, Final Report, March.

Roberts, S., 2008. Altering existing buildings in the UK. Energy Policy 36 (12), $4482-4486$.

Salat, S., 2009. Energy loads, $\mathrm{CO}_{2}$ emissions and building stocks: morphologies, typologies, energy systems and behaviour. Building Research and Information 37 (5-6), 598-609.

Stern, N., 2007. The Economics of Climate Change-The Stern Review. Cambridge University Press, UK.

Tambach, M., Hasselaar, E., Itard, L., 2010. Assessment of current Dutch energy transition policy instruments for the existing housing stock. Energy Policy 38 (2), 981-996.

Theodoridou, I., Papadopoulos, A.M., Hegger, M., 2011a. A typological classification of the Greek residential building stock. Energy and Buildings 43 (10), 2779-2787.

Theodoridou, I., Papadopoulos, A.M., Hegger, M., 2011b. Statistical analysis of the Greek residential building stock. Energy and Buildings 43 (9), 2422-2428.

Trachte, S., De Herde, A., 2010. Choix des matériaux-Ecobilan de parois. Technical Report, Service Public de Wallonie, DG04, Final Report.

Verhoeven, R., 2009. Pathways to World-class Energy Efficiency in Belgium. McKinsey \& Company-2009, Belgium.

Walloon Government, 2007. Arr|widehatete' du 17avril 2007du gouvernement wallon de'terminant la me'thode de calcul et les exigences, les agre'ments et les sanctions applicable en matiere de performance énerge'tique et de climat inte'rieur des b|widehatatiments, April.

\section{Further reading}

〈http://www.sustainablecity.be/content/news-brussels/2013-energy-subsidies-e ven-better-brussels-capital-region $\rangle$, Accessed on 6/07/2013a.

〈http://www.bruxellesenvironnement.be/Templates/Professionnels/niveau2.aspx? maintaxid=12326\&taxid=12326 $\rangle$, Accessed on 6/07/2013b.

〈http://www.iea.org/policiesandmeasures/energyefficiency/?country=Belgium〉, Accessed on $6 / 07 / 2013 c$

〈http://www.iea.org/policiesandmeasures/climatechange/?country=Belgium〉, Accessed on $6 / 07 / 2013 d$

〈http://www.eceee.org/buildings/EPBD_Recast〉, Accessed on 6/07/2013e. 